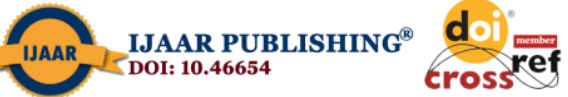

International Journal of Advanced Academic Research (Sciences, Technology and Engineering) | ISSN: 2488-9849

Journal DOI: 10.46654/ij.24889849

Vol. 6, Issue 9 (September, 2020) | www.ijaar.org

Article DOI: 10.46654/ij.24889849.e698

\title{
EFFECT OF HEAT TREATMENT METHOD ON THE HARDNESS AND CORROSION OF DUCTILE IRON IN 3.5\% SODIUM CHLORIDE SOLUTION
}

\author{
Oluyori, R. T' ${ }^{1}$; Alao, A. $O^{2}$; Barnabas, A. $A^{3}$; Shittu, S. $A^{3}$; Omole, S. $O^{3}$ and \\ Akinwande, A. $\mathrm{A}^{3}$ \\ ${ }^{1}$ Department of Metallurgy and Materials Engineering, Kogi State Polytechnic, Lokoja, Kogi \\ State, Nigeria. \\ ${ }^{2}$ Department of Foundry Engineering, Federal Polytechnic, Idah, Kogi State, Nigeria . \\ ${ }^{3}$ Department of Metallurgical and Materials Engineering, Federal University of Technology, \\ Akure, Nigeria. \\ Corresponding author's email: barnabelad0110@gmail.com
}

\begin{abstract}
In this research, the corrosion response of heat treated ductile cast iron (DCI) used in the production of engine crank shaft was examined. Five samples were used in this work, one of the samples served as control sample, the remaining four samples were subjected to conventional heat treated operations of annealing, normalizing and hardening. The nodular cast irons were heated to initial austenitic temperature of $900^{\circ} \mathrm{C}$, held for one (1hour) in the muffle furnace for homogenization, and samples were now cooled in furnace, air, water and oil respectively. Sodium chloride of $3.5 \%$ weight percentage solution was used as environment to study corrosion behaviour of the heat treated ductile cast irons. The microstructural images of the control and heat treated samples were resolved and various developed structures are essentially spheroidal graphite, and pearlitic matrix as in the case of the un-heat treated sample, coarse pearlite matrix for the annealed sample, fine pearlite structure for the normalized sample and partially martensitic and fully martensitic matrix for the oil and water quenched samples. Thus, sample quenched in oil releases an impression of being the materials with the most raised corrosion resistance as a result of more broad scope of passive layers. Oil quenched sample showed best resistance to corrosion in sodium chloride solution with corrosion rate value of $0.0064388 m m p y$, followed by the air cooled sample with corrosion rate value of 0.008512 mmpy. Un-heat treated sample has the highest corrosion rate of 0.2188 mmpy. The presence of martensite with less amount of residual improved the corrosion resistance of the ductile iron, also the presence of fine pearlite structure increases the resistance of ductile iron to corrosion in the chosen chloride environment.
\end{abstract}

Keywords: Ductile iron, electrochemical behaviour, conventional heat treatment, 3.5 sodium chloride solution. 


\subsection{Introduction}

Spheroidal cast iron is a well-known engineering material because of its high ductility and strength. It possess good mechanical properties and economic value. Spheroidal cast iron is also known as nodular cast iron. Graphitization of carbon is usually achieved by addition of magnesium or cerium as graphite inoculants that cause the formation of graphite nodules (Monchoux et al., 2000).

The behaviour of graphite at high temperature is vital for selecting heat treatment conditions. The two potent mechanisms for determining graphite nodule behaviour are diffusion and globalization. These graphite nodules are wholly carbon except inoculating material (Selcuk and Kelami 2017). The surface of nodules are said to be in contact with low carbon iron matrix. Carbon in nodules and iron in matrix can be made activative when temperature is increasing. Meanwhile, globalization mechanism help in the formation of spheroid shaped nodule that does not fall apart (Monchoux et al., 2001).

Elemental compositions of ductile cast iron vary from one production to another. Spheroidal graphite irons may be heat-treated for either to produce matrix structure to achieve desired mechanical properties for the different grades of nodular iron, to graphitize carbides which may be present as a result of poor inoculation, due to incorrect composition or segregation in the heat affected zone of welds, to improve the surface wear and/or friction characteristics, to improve machinability, or to effect stress relief. In order to achieve desired properties, nodular cast irons are usually subjected to annealing, normalizing, and hardening and tempering and stressrelieving heat treatment. In the recent years, low cost of production and preferable properties like castability and good fluidity of ductile iron in some working conditions. Engine sleeves do break down in service because of increasing corrosion product formation on it when it is exposed to source of oxygen (Ojo et al., 2019 and Reynaud, 2010). DI has some unique properties that make it serviceable in most engineering industries, such as wear resistance, good machinability, and better mechanical properties that improve its use in some difficult condition (Benyounis et al., 2005 and Yan et al., 2010). Modifying the properties of ductile iron by some heat treatment condition to form austempered ductile iron will increase the wear performance in service condition (Sohi et al., 2012). The formation of $\mathrm{Fe} 2 \mathrm{O} 3$ at the oxide interface, trailed by $\mathrm{Fe} 3 \mathrm{O} 4$ and lastly $\mathrm{FeO}$ are the general oxidation experienced with ductile cast iron in air (Sohi et al., 2012, Yan et al., 2010 and Hsu et al., 2010). Gulzar et al. (2009) opined that low silicon content in the cast iron can lead to changes in its weight at a temperature of $800^{\circ} \mathrm{C}$. The migration of ferrous ions from the metal surface to the environment naturally increases as the corrosion product of ductile iron cast iron increases (Tholence and Norell, 2002, Sancy et al., 2010, Lou et al., 2006 and Hemanth, 2006). Investigation revealed that in spheroidal graphite, corrosion resistance decreases as the spheroid size decreases (Hsu et al., and Lou et al., 2006). Previous, work talks about corrosion behaviour of ductile cast iron and austempered ductile iron in $0.01 \mathrm{M}$ and $0.05 \mathrm{M}$ of $\mathrm{NaCl}$. This paper examines the microstructure of the un-heat treated and heat treated ductile cast iron and their corrosion behaviours in $3.5 \% \mathrm{NaCl}$ solution.

\subsection{Experimental}

\section{Material and preparation}

The production of this ductile iron and the conventional ductile used in this study was carried out in a $60 \mathrm{~kg}$ pit furnace in foundry laboratory at the Metallurgical and Materials Engineering Department of Federal University of Technology, Akure, Nigeria. The sand mould was prepared into the geometric shape of the expected cast shape and size. At a temperature slightly 
above the melting point of the alloy, it was directly released into a preheated ladle of $20 \mathrm{~kg}$ capacity and the nodulizing process was undertaken with the calculated quantity of Fe-Si-Mg alloy. Then, the ladle was inoculated by addition of $\mathrm{Fe}-\mathrm{Si}$ in the melt. Before pouring the melt into the mould, mechanical stirring was done at temperature of $1400^{\circ} \mathrm{C}$. The produced samples were austenitized at temperature of $900^{\circ} \mathrm{C}$, which was done in a muffle furnace and the samples were taken out of the furnace and later cooled in air, furnace, oil and water respectively.

The samples were dimensioned into size of $10 \mathrm{~mm} \times 10 \mathrm{~mm} \times 3 \mathrm{~mm}$ and all specimens were prepared. Samples prepared for microstructural studies were ground carefully using 120, 320, 600,800 , and 1200 grit size of silicon carbide sand papers followed by polishing using a 0.3 microns silicon carbide abrasive powder. Samples were then etched with $2 \%$ Nital solution; 2 $\mathrm{ml}$. of nitric acid mixed with $98 \mathrm{ml}$ of ethanol. All the chemical agents were obtained from Pascal Scientific Laboratories at United Kingdom. Microstructure studies were performed using the Zeiss optical microscope and the analysing software.

The Chemical Compositions of the Ductile Cast Iron are shown below;

Table 2.1: Chemical Composition of the Ductile Iron

\begin{tabular}{lllllllllll}
\hline Elements & $\mathrm{C}$ & $\mathrm{Si}$ & $\mathrm{Mn}$ & $\mathrm{S}$ & $\mathrm{P}$ & $\mathrm{Cr}$ & $\mathrm{Ni}$ & $\mathrm{Cu}$ & $\mathrm{Mg}$ & $\mathrm{Fe}$ \\
\hline Value & 3.61 & 2.83 & 0.38 & 0.015 & 0.025 & 0.04 & 0.05 & 0.56 & 0.06 & 92.43 \\
& & & & & & & & & & \\
\hline
\end{tabular}

\subsection{Tests Measurements:}

Hardness Measurement-The heat treated samples were polished in emery papers of different grades for hardness measurement. Rockwell Hardness test was performed at room temperature to measure the macro hardness of the ductile iron specimens in a scale. The load was applied through the diamond indenter for few seconds during testing of all the treated and untreated samples. Four measurements for each sample were taken covering the whole surface of the specimen and averaged to get final hardness results. A load of $60 \mathrm{~kg}$ was applied to the specimen for 30 seconds. Then the depth of indentation was automatically recorded on a dial gauge in terms of arbitrary hardness numbers.

\subsection{Corrosion experiment}

Corrosion test was carried out at 3.5 wt. \% of sodium chloride using a Versa-studio Potentio-Stat equipped with a three-cell corrosion set up. This comprises silver/silver chloride $(\mathrm{Ag} / \mathrm{AgCl})(3$ $\mathrm{M} \mathrm{KCl})$ reference electrode, graphite counter electrode, and a working electrode prepared by attaching a copper wire to the other end of sample using aluminium foil tape, exposing a contact area of $1 \mathrm{~cm}^{2}$ of the samples. Prior to immersion of working electrode in corrosive media, samples surfaces, which were cold, mounted in epoxy resins were ground on till a smooth surface were obtained. All tests were conducted at $25^{\circ} \mathrm{C}$ temperature, and tests were repeated for reproducibility. Scan rate of $0.166 \mathrm{mV} / \mathrm{s}$ was used to raising electrode potential from -0.25 to $0.25 \mathrm{~V}$. 
International Journal of Advanced Academic Research (Sciences, Technology and Engineering) | ISSN: $2488-9849$

Vol. 6, Issue 9 (September, 2020) |www.ijaar.org

Journal DOI: 10.46654/ij.24889849

Article DOI: 10.46654/ij.24889849.e698

\subsection{RESULTS AND DISCUSSION}

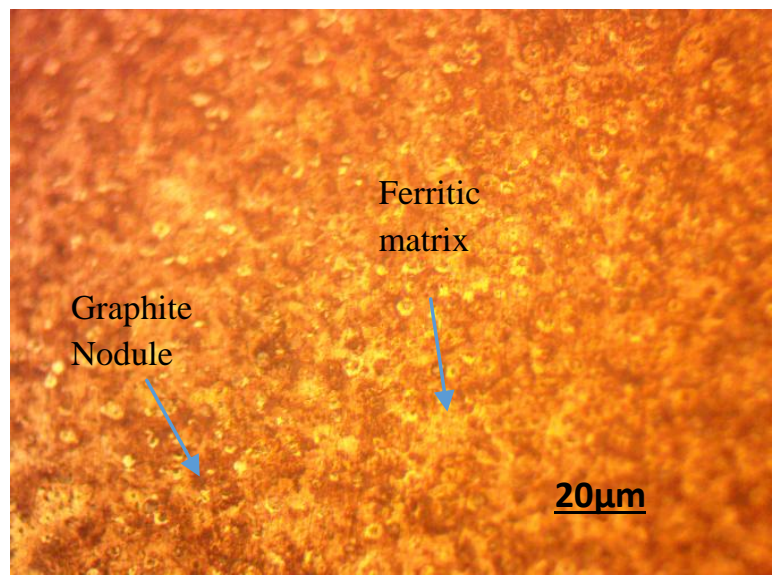

Control sample

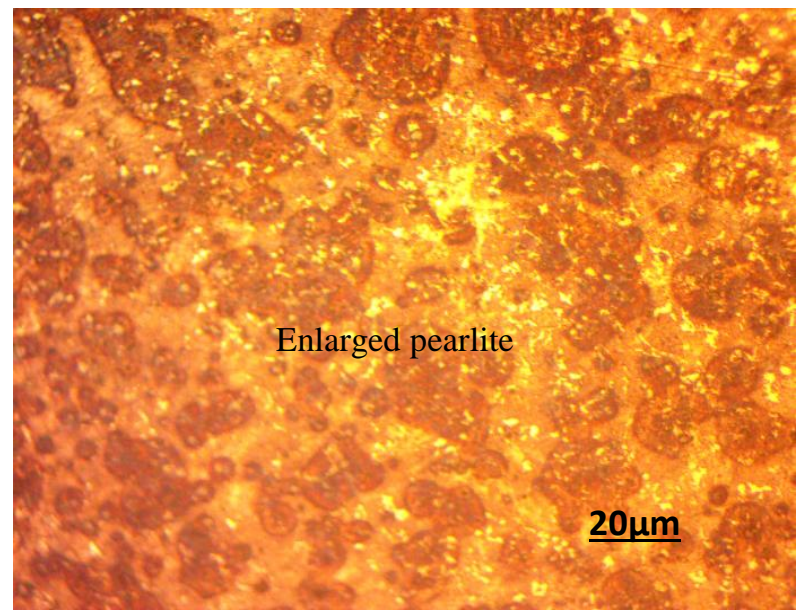

Furnace cooled sample

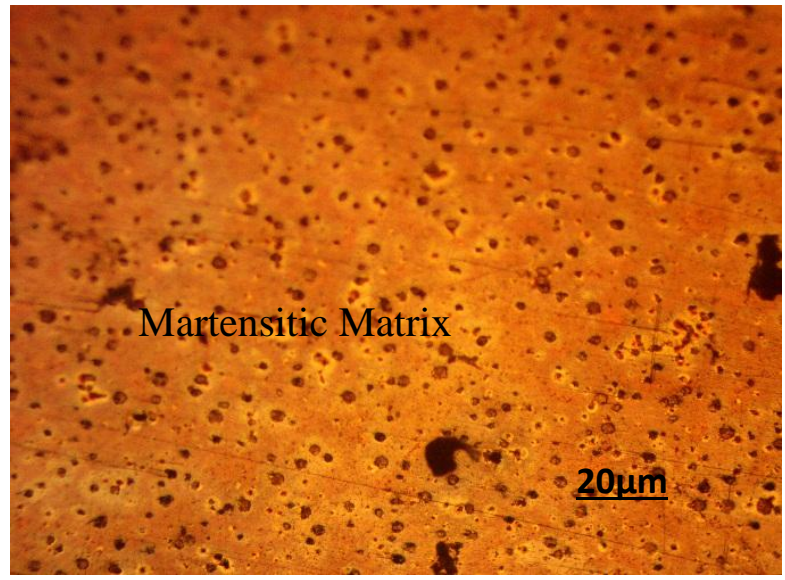

Water Quenched sample

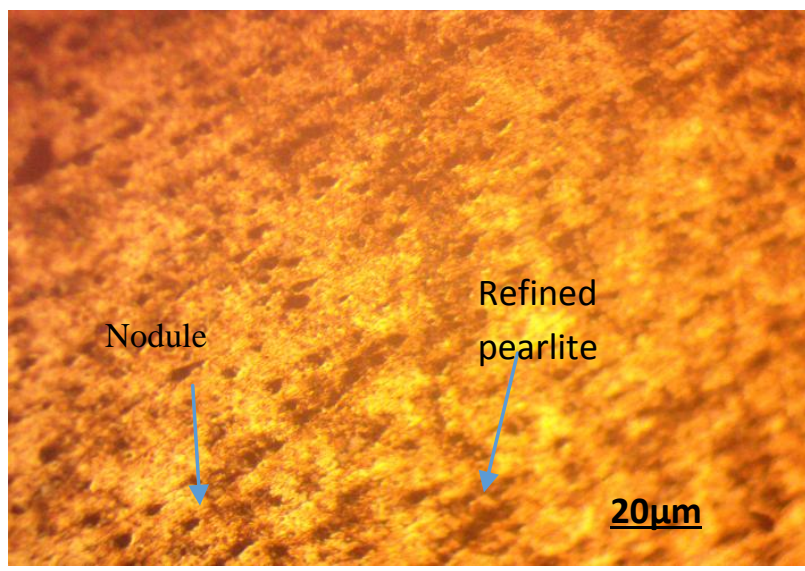

Air cooled sample

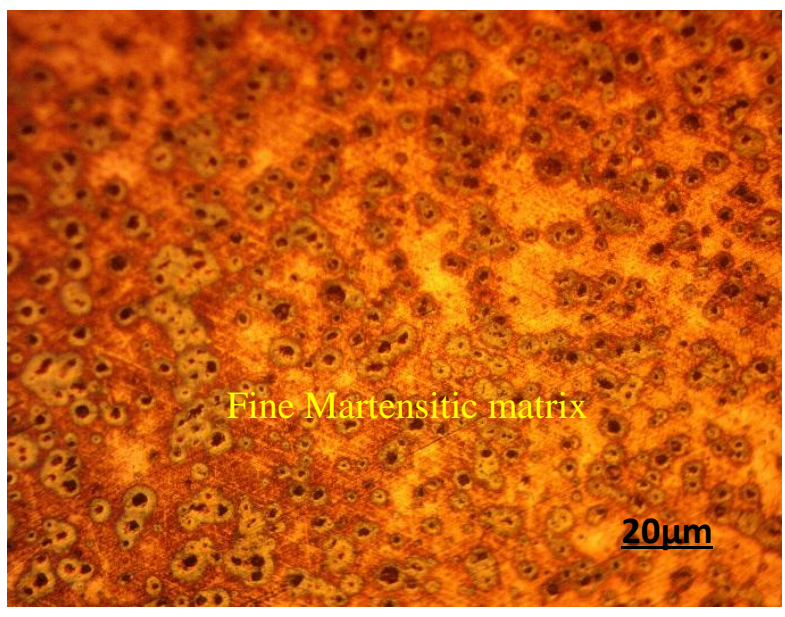

Oil cooled sample 
International Journal of Advanced Academic Research (Sciences, Technology and Engineering) | ISSN: 2488-9849 Vol. 6, Issue 9 (September, 2020) | www.ijaar.org

Journal DOI: 10.46654/ij.24889849

Article DOI: 10.46654/ij.24889849.e698

\subsection{Hardness results}

The hardness result of the as - received and heat treated ductile iron cooled in different media is presented below:

Table 3.1: Hardness results of the as- received and heat treated ductile iron in different media

S /N Media Hardness (HRC)

\begin{tabular}{llc}
\hline 1 & WATER & 55.8 \\
2 & FURNACE & 24.4 \\
3 & OIL & 48.7 \\
4 & AIR & 32.0 \\
5 & CONTROL & 27.0 \\
\hline
\end{tabular}

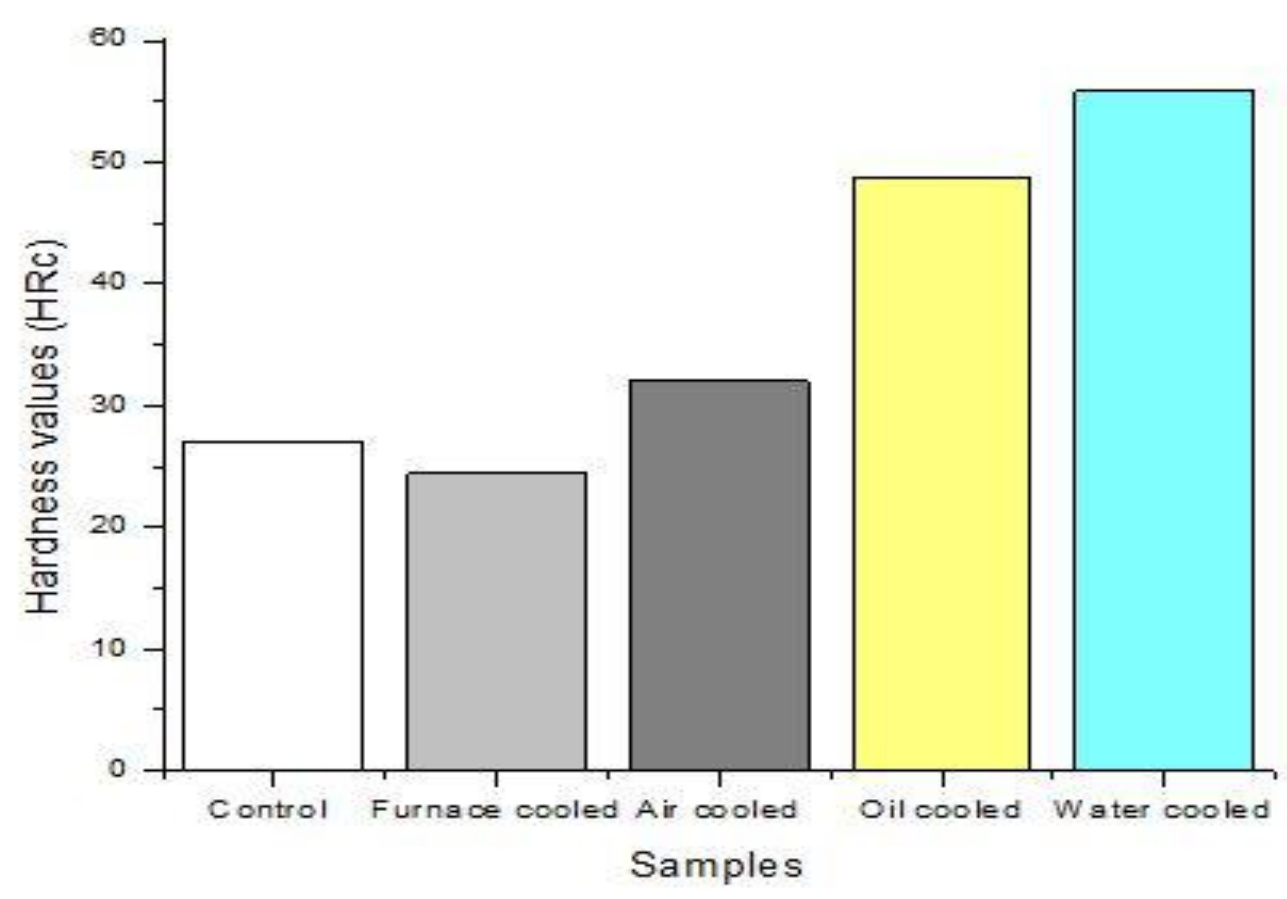

Figure 3.1: Plot of hardness values against samples 


\subsubsection{Corrosion results}

The Tafel data were extrapolated to obtain Ecorr, Icorr and corrosion rate of the heat treated ductile iron are presented in Table 4.3 and Figure 4.1 respectively.

Table 3.2: Polarization data for heat treated ductile iron in sodium chloride solution.

\begin{tabular}{llll}
\hline Sample & $\mathbf{E}_{\mathbf{c o r r}}(\mathbf{m v})$ & $\mathbf{I}_{\mathbf{c o r r}}(\mathbf{u} \mathbf{A})$ & $\begin{array}{l}\text { Corrosion } \\
(\mathbf{m m p y})\end{array}$ \\
\hline Control & -681.778 & -18.856 & 0.2188 \\
Water & -760.391 & -2.082 & 0.024161 \\
Air & -662.301 & $-733 . .591$ & 0.0085123 \\
Furnace & -681.803 & -4.656 & 0.054036 \\
Oil & -764.078 & -554.802 & 0.0064377 \\
\hline
\end{tabular}

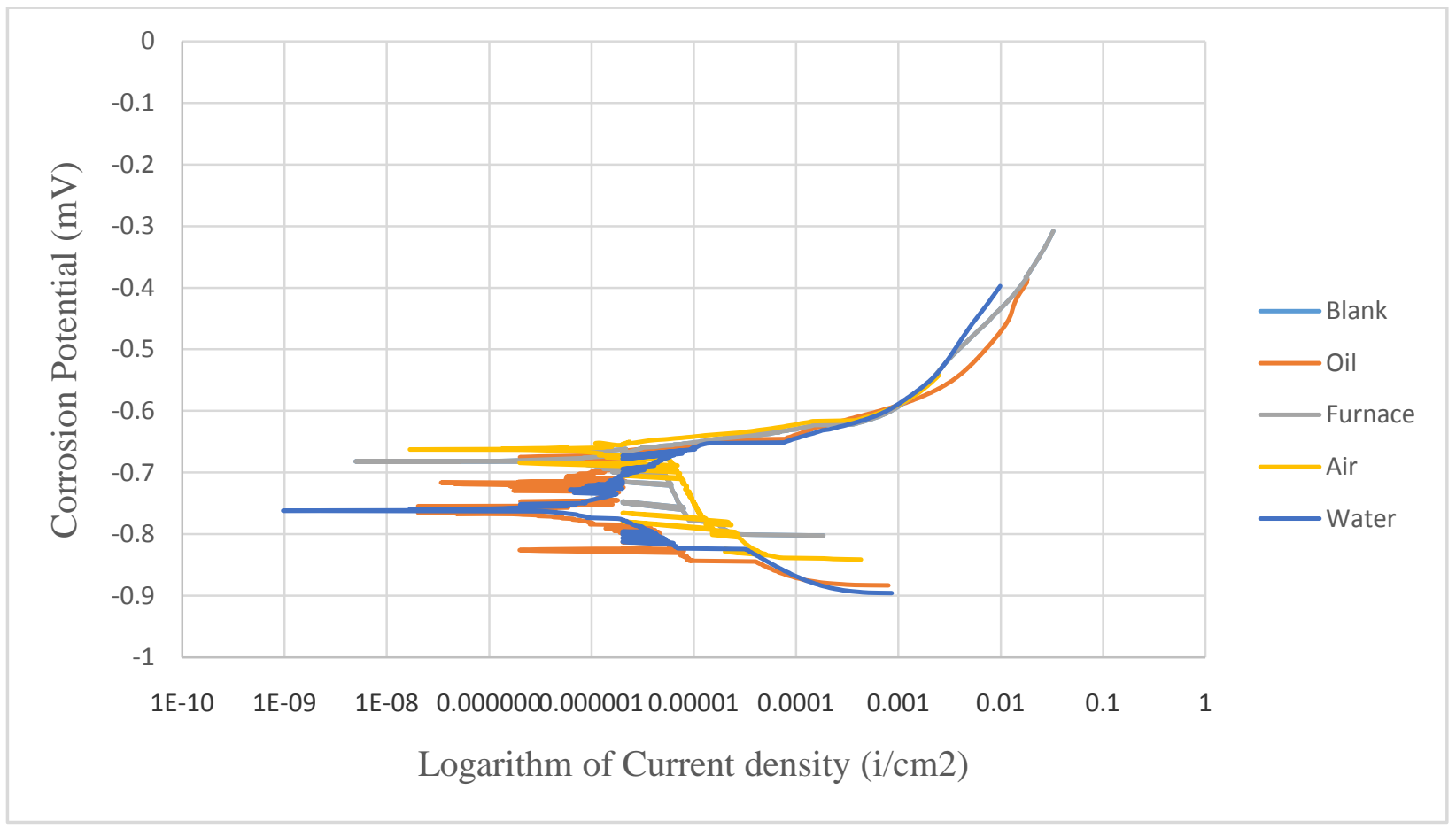

Figure 3.2: polarization curves of as - received and heat treated ductile iron cooled in different media. 


\section{DISCUSSION}

\subsection{Hardness results}

The hardness results earlier presented in Table 3.1 shows increase in hardness of all the heat treated samples except those cooled in the furnace. Maximum hardness was observed in the ductile iron specimen cooled in water with the hardness value of $55.8 \mathrm{HRC}$. This is followed by specimen quenched in oil and those cooled in air with hardness value 48.7 and 32.0 HRC respectively. The lowest hardness of $24.4 \mathrm{HRC}$ was exhibited by specimens cooled in the furnace. The difference in hardness is mainly due to cooling rate differences. The hardness of the water - cooled specimen may be probably due to nucleation and growth of acicular ferrite within the austenite, where carbon is injected into the austenite. The high hardness of the watercooled specimens could also be traceable to fast cooling rate of the specimens which results in more amount of treated martensite at room temperature. This is evidenced in the resulting microstructure with ferrite in carbon enriched austenite.

The reduction in hardness of the oil-cooled specimen compared to the specimen cooled in water might be probably due to the fact that the cooling rate of oil is much less than water. It is generally observed that oil - based fluids often oxidized and form a sledge during quenching, and consequently results in lower hardness. The reduction in hardness of the oil-cooled specimens may equally be due to the fact that oil has less viscous due to fast cooling of the normalized (air-cooled) specimen, austenite is decomposed in ferrite and carbide at relatively lower temperature and the fine pearlite is produced. This process (normalizing) enhanced the hardness of the ductile iron as compared to the specimen cooled in the furnace.

The furnace cooled specimen has the least hardness value. This is because of elongation and grain growth which enhances ductility at the expense of hardness. In the annealed and normalizing specimen, hardness values were lower as compared to the water cooled specimen, this may be due to compaction of coarse grains at high temperature and slowly cooling rate, as reflected in their microstructures.

In general, the heat treated specimens exhibited better hardness than as-received specimens with the exception of the furnace cooled specimen where ductile was enhanced.

\subsection{Corrosion results}

The results of the corrosion progression from the linear polarization study were earlier presented in figure 3.1. The Tafel data were extrapolated to obtain $\mathrm{E}_{\text {corr }}, \mathrm{I}_{\text {corr }}$ and corrosion rate respectively in Table 3.2. The results revealed that corrosion rate is affected by rate of cooling of the samples in the different media. It is observed that the heat treated specimens were more resistant to corrosion in sodium chloride solution as compared to as-received specimens. The corrosion rate of the specimens in their respective cooling media are $0.024161 \mathrm{mmpy}$ for water, $0.0085123 \mathrm{mmpy}$ for air, $0.054036 \mathrm{mmpy}$ for furnace, $0.0064377 \mathrm{mmpy}$ for oil, and $0.2188 \mathrm{mmpy}$ for the as - received specimen. A careful look at the results show that the specimen quenched in the oil has the least corrosion rate. This is exhibited in its good corrosion potential which shows that the cooling rate provided a better corrosion resistant effect (Jones, 1996). This may be due to the formation of thin film which retarded the ingress of chloride ions into the specimen surface. It can be seen in the microstructure as there is low evidence of corrosion attack and 
dark spots. There are good area fractions of ferrite (white background) in the microstructure compared to the area fraction of pearlite.

This is followed by the normalized specimen with corrosion rate of $0.0085123 \mathrm{mmpy}$. The corrosion performance may be due to the formation of thin film which posed a barrier between the surface of the ductile iron and the environment. The increased corrosion rate of this specimen compared to the oil cooled specimen is evidence of localized attack, bigger and darker spots in the microstructure.

The specimen cooled in the furnace exhibited a corrosion rate of $0.054036 \mathrm{mmpy}$. The increase in corrosion rate of the furnace cooled specimen when compared to the normalizing specimen may be due to slow cooling which resulted in reduced strength and hardness.

The water - quenched specimen has corrosion rate of $0.024161 \mathrm{mmpy}$. They showed better corrosion performance than the specimen cooled in the furnace. This may probably be due to the injection of carbon into the austenite resulting in the formation of acicular ferrite in carbon enriched austenite which enhanced corrosion and wear properties.

The as-received specimen displayed the highest corrosion rate in the corroding medium. This is obvious in the microstructure with attendant darker spot.

The corrosion behavior of the specimens in their respective media is further observed in the linear potentiodynamic curves of the specimens. It is obvious from this curve that there is favorable corrosion potential which enhanced the corrosion performance of the heat treated specimens.

In all the heat treated specimen gave better corrosion resistance effect compared to the as received specimen. The earlier discussions are corroborated by the micrographs in Figure (3.2a $-\mathrm{f})$.

\section{CONCLUSION AND RECOMMENDATION}

\subsection{Conclusion}

The following conclusions can be drawn from this work:

1. The hardness and corrosion properties of ductile iron were affected by heat treatment.

2. Hardness is enhanced with the water-cooled specimens exhibiting maximum hardness property and can be suggested for application where maximum hardness is desired.

3. The specimen quenched in oil exhibited the best corrosion resistance in sodium chloride solution.

4. The heat treated specimens are more resistant to corrosion than the as - received specimen.

5. The microstructure evolved from the heat treated specimens resulted in better hardness and corrosion resistance property than as-received specimen in sodium chloride solution. 


\section{REFERENCES}

A. Reynaud, Corrosion of cast irons vol. 3: Elsevier, 2010.

A. Gulzar, J. Akhter, M. Ahmad, G. Ali, M. Mahmood, and M. Ajmal, "Microstructure evolution during surface alloying of ductile iron and austempered ductile iron by electron beam melting," Applied Surface Science, vol. 255, pp. 8527-8532, 2009.

C.-H. Hsu and M.-L. Chen, "Corrosion behavior of nickel alloyed and austempered ductile irons in 3.5\% sodium chloride," Corrosion Science, vol. 52, pp. 2945-2949, 2010.

D. Lou, O. Akselsen, M. Onsøien, J. Solberg, and J. Berget, "Surface modification of steel and cast iron to improve corrosion resistance in molten aluminium," Surface and Coatings Technology, vol. 200, pp. 5282- 5288, 2006.

F. Tholence and M. Norell, "AES characterization of oxide grains formed on ductile cast irons in exhaust environments," Surface and interface analysis, vol. 34, pp. 535-539, 2002.

H. Yan, A. Wang, Z. Xiong, K. Xu, and Z. Huang, "Microstructure and wear resistance of composite layers on a ductile iron with multicarbide by laser surface alloying," Applied Surface Science, vol. 256, pp. 7001- 7009, 2010.

J. Hemanth, "The solidification and corrosion behaviour of austempered chilled ductile iron," Journal of Materials Processing Technology, vol. 101, pp. 159-166, 2000.

Jones D. A. (1996) : Principles and prevention of Corrosion, $2^{\text {nd }}$ ed. Prentice Hall,Upper Saddle River, New Jersy, US, pp.516-520.

K. Benyounis, O. Fakron, J. Abboud, A. Olabi, and M. Hashmi, "Surface melting of nodular cast iron by Nd-YAG laser and TIG," Journal of Materials Processing Technology, vol. 170, pp. 127-132, 2005.

M. H. Sohi, M. Ebrahimi, H. Ghasemi, and A. Shahripour, "Microstructural study of surface melted and chromium surface alloyed ductile iron," Applied Surface Science, vol. 258, pp. 7348-7353, 2012.

M. Sancy, Y. Gourbeyre, E. Sutter, and B. Tribollet, "Mechanism of corrosion of cast iron covered by aged corrosion products: Application of electrochemical impedance spectrometry," Corrosion Science, vol. 52, pp. 1222-1227, 2010.

Monchoux J.P., Verdu C., Thollet G., Fougeres R., 2000: Effect of a Ferritization Heat Treatment on the Fracture Toughness of Ferritic spheroidal Graphite Cast Iron, Scripta Materiala, Vol. 42, Pp 1047 - 1052.

Monchoux J.P., Verdu C., Thollet G., Fougeres R., Reynaud A., 2001: Morphological Changes of Graphite Spheroids during Heat Treatment of Ductile Cast Irons, ActaMateriala, Vol. 49, Pp 1355 - 4362

Ojo Jeremiah Akinribide, Samuel Olukayode Akinwamide, Olawale Olarewaju Ajibola, Babatunde Abiodun Obadele, Samuel Oloruntoba Oluwagbenga Olusunle and Peter Apata Olubambi, 2019: Corrosion Behaviour of Ductile and Austempered Ductile Cast 
International Journal of Advanced Academic Research (Sciences, Technology and Engineering) | ISSN: $2488-9849$

Journal DOI: 10.46654/ij.24889849

Vol. 6, Issue 9 (September, 2020) |www.ijaar.org

Article DOI: 10.46654/ij.24889849.e698

Iron in 0.01M and 0.05M NaCl Environments, Procedia Manufacturing, No 30, Pp 167 172.

Selcuk Yesiltepe and M. Kelami Sesen, 2017: Heat Treatment Effect on Spheroidal Graphite,

Microstructure and Mechanical Properties of Ni-Resist ductile Cast Iron, Journal of Engineering sciences and Design. Vol.5, Issue 3, Pp 479 - 482. 